\title{
Development of a Flow-Injection with Spectrophotometric Method for Total Iron in Water Samples
}

\section{Su Örneklerinde Toplam Demir Tayini için Spektrofotometrik Akış Enjeksiyon Yöntemi Geliştirilmesi}

Research Article

Adem Asan' and Bediha Akmeşe ${ }^{2 *}$

'Ondokuz Mayis University, Department of Chemistry, Faculty of Art and Science, Kurupelit, Samsun, Turkey. ${ }^{2}$ Hitit University, Department of Chemistry, Faculty of Art and Science, Çorum, Turkey.

\section{A B S TR AC T}

\begin{abstract}
A simple spectrophotometric flow-injection method is reported for the highly sensitive and fast determination of iron(III) and total iron. The method is based on the formation of iron(III)- (1-nitroso-2-naphthol-3,6 sulphonate) (NRS) complex. The optimum conditions for the reaction of iron(III) with NRS is studied. And the complex is selectively monitored at $\lambda_{\max } 370 \mathrm{~nm}$. With the reagent carrier solvent used was $5 \times 10^{-4} \mathrm{M}^{1-n i t r o s o-}$ 2-naphthol-3,6 sulphonate in $0.1 \mathrm{M}$ acetic acid-acetate buffer solution at pH 4.0. Parameters affect simultaneously for the determination of iron(III) and interfering ions were tested. Relative standard deviation for five consecutive injections of $70 \mu \mathrm{g} . \mathrm{L}^{-1}$ iron(III) was $1.46 \%$ and for $5 \mu \mathrm{g} . \mathrm{L}^{-1}$ iron(III), it was $3.12 \%$. The calibration graph was linear in the iron(III) concentration range $0.1-100 \mu \mathrm{g} . \mathrm{L}^{-1}$ and the limit of detection was $0.05 \mu \mathrm{g} . \mathrm{L}^{-1}$ for a $20 \mu \mathrm{L}$ injection volume. The precision and accuracy of the method were checked by analysis of certified reference material and AAS method. The method was successfully applied to determine trace amounts of iron(III) and total iron in river and sea water samples.
\end{abstract}

\section{Key Words}

Flow-Injection Analysis, Iron, Spectrophotometric Determination, 1-Nitroso-2-naphthol-3,6 sulphonate.

\section{öz}

\begin{abstract}
$\mathrm{D}$ emir(III) ve toplam demirin oldukça hassas ve hızlı tayin edilmesi için basit bir spektrofotometrik akış enjeksiyon yöntemi geliştirilmiştir. Yöntem, demir(III) ile 1-nitrozo-2-naftol-3,6 sülfonat (NRS) reaktifi arasında oluşan gelen kompleksin oluşumuna dayanmaktadır. Demir(III) ile NRS tepkmesi için optimum koşullar belirlenmiş ve kompleks $\lambda_{\max } 370 \mathrm{~nm}$ 'de spesifik absorpsiyon dalga boyuna sahip olduğu görülmüştür. Hareketli faz olarak pH 4.0'de 0.1 M asetik asit-asetat tampon çözeltisinde 5x10-4 M derişimde I-nitrozo-2-naftol-3,6 sülfonat tuzu kullanılmıştır. Demir(III) tayininde kullanılan parametreler ve girişim yapan iyonlar test edildi. Peş peşe yapılan $70 \mu \mathrm{g} . \mathrm{L}^{-1}$ derişimdeki demir(III) enjeksiyonu için bağıl standart sapma \%1.46 ve $5 \mu \mathrm{g} \mathrm{L}$ L $^{-1}$ derişimdeki demir(III) için ise elde edilen bağıl standart sapma \%3.12 olarak belirlendi. Doğrusal çalışma bölgesinin 0.1-100 $\mu \mathrm{g} . \mathrm{L}^{-1}$ demir(III) derişim aralığında olduğu belirlendi ve $20 \mu \mathrm{L}$ enjeksiyon hacmi için tayin sınırı $0.05 \mu \mathrm{g} . \mathrm{L}^{-1}$ olarak bulundu. Yöntemin kesinliği ve doğruluğu, standart referans madde ve AAS yöntemi ile analiz edilerek test edildi. Yöntem, nehir ve deniz suyu numunelerinde demir(III) ve toplam demirin eser miktarlarını belirlemek için başarıyla uygulanmıştır.
\end{abstract}

\section{Anahtar Kelimeler}

Akış-Enjeksiyon Analizi, Demir, Spektrofotometrik Tayin, I-Nitrozo-2-naftol-3,6 sülfonat.

Article History: Received: Mar 10, 2017; Revised: Sep 21, 2017; Accepted: Oct 30, 2017; Available Online: Dec 25, 2017. DOI: 10.15671/HJBC.2018.192

Correspondence txxo: B. Akmeşe, Hitit University, Department of Chemistry, Faculty of Art and Science, Çorum, Turkey. 


\section{INTRODUCTION}

ron is considered as an essential mineral because it is needed to make part of our blood cells. Iron is the most abundant transition metal in the living system and serves more biological roles than any other metal. Iron, a vital element in the environment and biology, is widely distributed in nature [1]. Iron is one of the most important elements in metabolic processes, being indispensable for plants and animals and therefore it is extensively distributed in environmental and biological materials. Owing to the active role of iron in aquatic redox processes, the determination of the two oxidation states of his element, Fe(II) and $\mathrm{Fe}(\mathrm{III})$, is great importance for estimating properties relevant to biological or geochemistry, such as the solubility, photochemistry and colloidal chemistry of the element [2,3]. UVvisible spectrophotometry, atomic absorption spectrometry, inductively coupled plasma-mass spectrometry, cathodic stripping voltametry, fluorimetry and ion chromatography [4-9] have been used for determination of iron.

The association of FIA with UV-vis spectrophotometry is the most effective and suitable approach for routine analysis, mainly owing to its simplicity, low instrumental and operation cost high analysis rate and robustness. For this reason, it has been widely applied to the flow-injection determination of iron in several sample matrices [10-13]. Iron has been selectively determined in flow-injection systems by forming complexes with chelating agents which often showa suitable absorption at a characteristic wavelength [14-16]. A number of other chelating agents that have been reported for the spectrophotometric and/or flow-injection spectrophotometric determination of iron(III) and total iron include norfloxacin [17], 3-aminophtalhydrazide [18], 8-hydroxy-quinoline [19], SCN- [20]. Flow-injection analyses (FIA), especially for spectrophotometric determination of metallic ions, have gained much interest in recent years because of their simplicity, high reproducibility and possibility of coupling different detection systems.

In our previous studies [21-23] simple flowinjection analysis methods was developed for the selective and sensitive determination of iron(II),
iron(III) and total iron in sea and river water samples by using different complexing agents. In the present study, an ultra-sensitive and highly selective, simple and economic flow-injection spectrophotometric procedure using 1-nitroso2-naphthol-3,6 sulphonate (Nitroso R-salt) (NRS) has been described for the determination of iron(III) and total iron. The reagent of the 1-nitroso-2-naphthol-3,6 sulphonate was used for the determination of iron $[24,25]$. The developed method is based on the detection of change in the composition of the between iron and NRS reaction. The advantages of the proposed method are simple, ultra-sensitive and inexpensive. In the procedure, the NRS in the reagent carrier solution, selectively reacts with iron(III) forming a complex with absorption maxima at $370 \mathrm{~nm}$. The chemical structure of NRS is shown Figure 1.

This paper describes a rapid, selective and sensitive spectrophotometric FI method for direct determination of iron(III) at low $\mu \mathrm{g} . \mathrm{L}^{-1}$ levels in environmental samples. The reagent complexes with iron(III) to show absorption in the UV-vis region of the spectrum. Total iron was determined after oxidation of iron(II) to iron(III) with hydrogen peroxide. The effect of various parameters were investigated and the method was applied to the determination iron species in different water samples.

\section{EXPERIMENTAL}

\section{Reagent and Chemicals}

All chemicals used were of analytical reagent grade or the highest purity available. Double distilled deionized water was used throughout this

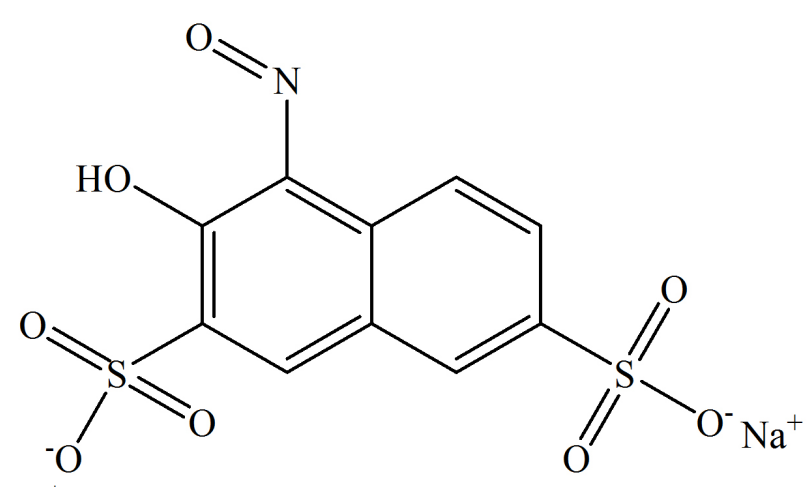

$\mathrm{Na}^{+}$

Figure 1. The chemical structure of 1-nitroso-2-naphthol-3,6 sulphonate (NRS). 


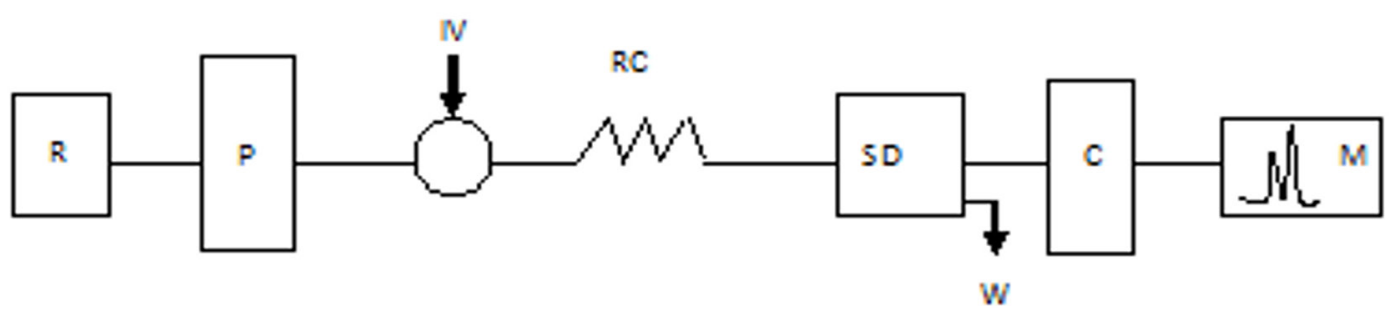

Figure 2. Schematic diagram of the flow-injection system used for spectrophotometric determination of iron(III). R; reagent carrier solution, $\mathrm{P}$, Peristaltic pump, IV; Rheodyne sample injection valve, RC; reaction coil, SD; spectrophotometric detector, W; waste, C; computer, M; monitor.

study. Glass vessels were cleaned by soaking in acidified solutions of $\mathrm{KMnO}_{4}$ or $\mathrm{K}_{2} \mathrm{Cr}_{2} \mathrm{O}_{7}$ followed by washing with concentrated $\mathrm{HNO}_{3}$, and were rinsed several times with high-purity deionized water. Stock solutions and environmental water samples (1000 $\mathrm{mL}$ each) were kept in polypropylene bottles containing $1 \mathrm{~mL}$ of concentrated $\mathrm{HNO}_{3}$.

Standard iron(II) and iron(III) stock solutions $\left(5 \times 10^{-3} \mathrm{M} \mathrm{Fe}(\mathrm{II})\right.$ and $\left.\mathrm{Fe}(\mathrm{III})\right)$ were prepared by dissolving $\mathrm{FeNH}_{4}\left(\mathrm{SO}_{4}\right)_{2} \times 12 \mathrm{H}_{2} \mathrm{O}$ and $\mathrm{Fe}\left(\mathrm{NH}_{4}\right)_{2}\left(\mathrm{SO}_{4}\right)_{2} \times 6 \mathrm{H}_{2} \mathrm{O}$ in water and were standardized by titration with EDTA. Standard solutions of iron(II) and iron(III) were daily prepared by several dilutions of the stock solution with double deionized water. Certified reference material $\mathrm{Zn} / \mathrm{Al} / \mathrm{Cu} 43 \mathrm{XZ3F}$ (consisting of $0.085 \%$ iron) was provided by MBH Analytical Ltd. (UK).

A stock solution of the NRS $\left(5 \times 10^{-3} \mathrm{M}\right)$ was prepared by dissolving requisite amount of the NRS (Aldrich) in deionized water.

Hydrogen peroxide and standard solution of other metal ions all of them from Merck (Darmstadt, Germany). Different concentrations of the metal solution were prepared with double distilled water.

Iron(III) ion react with NRS in aqueous medium. Metal-(NRS) ${ }_{n}$ complexes were prepared by mixing $1 \mathrm{~mL}$ of $1 \times 10^{-4} \mathrm{M}$ standard solution of each metal cation suitable volume of $1 \times 10^{-4} \mathrm{M}$ NRS in double deionized water. Reagent carrier solution was composed of NRS in 0.1 M HAc/Ac- buffer ( $\mathrm{pH}: 4.0$ ) prepared using acetic acid and sodium acetate.

\section{Apparatus}

UV-Visible spectra of metal-(NRS) ${ }_{n}$ complexes were taken with a UV-visible spectrophotometer (GBC Cintra 20, Australia). The pH measurements were made with a Jenway 3040 Model digital pHmeter.

In the FIA system, The absorbance of the ironNRS complexes were measured with a UV-Visible spectrophotometer $\left(\lambda_{\max }: 370 \mathrm{~nm}\right)$ equipped with a peristaltic pump (ISMATEC; IPC, Switzerland) $0.50 \mathrm{~mm}$ i.d. PFTE tubing was used to propel the samples and reagent solutions. Samples were injected into the carrier stream Rheodyne injection valve that can be adjusted in the range of 5-50 $\mu \mathrm{L}$ sample loops and connected to a computer that incorporated with a PC1000 software program.

Flame atomic absorption spectrophotometer (ATI UNICAM 929) was also employed (the measuring conditions were as follows: UNICAM hollow cathode lamp, $10 \mathrm{~cm}$ 1-slot burner, airacetylene flame (fuel gas flow-rate 1.50 L. $\mathrm{min}^{-1}$ ), $0.2 \mathrm{~nm}$ spectral bandwidth, and $7 \mathrm{~mm}$ burner height. The wavelength and the lamp current of iron was respectively $248 \mathrm{~nm}$ and $5 \mathrm{~mA}$ ) for the determination of iron content of water samples in reference to the FIA method.

\section{General Procedure}

The FIA system used is simple and shown schematically in Figure 2. The sample solution was introduced into the reagent carrier solution by the Rhodyne injection valve. NRS and iron(III) were reacted completely on $70 \mathrm{~cm}$ reaction coil (RC) resulting in a iron(III)-NRS complex and then passed through the flow through cell using to measure the absorbance at $370 \mathrm{~nm}$. The signal was recorded as a peak, the height of which was proportional to the iron(III) concentration in the sample, and was used for all measurements. In 
order to reproducibility, five replicate injections per sample were made. Total iron was determined by oxidizing the whole sample iron(II) to iron(III) in the procedure described [21].

\section{Sample Preparation Procedures}

Sea water (Black Sea, Samsun, Turkey) and stream water (River Mert, Samsun) samples were collected in prewashed polyethylene bottles. Samples were filtered (a cellulose nitrate membrane of pore size $0.45 \mu \mathrm{m}$ Millipore Filter (Millford, MA) before use. Samples were stored at $4^{\circ} \mathrm{C}$ until analysis. Analyses were performed with the least possible delay. Before the analysis, $1 \mathrm{~mL}$ of $1 \mathrm{~mL}$ of $\mathrm{H}_{2} \mathrm{O}_{2}(10 \% \mathrm{w} / \mathrm{w})$ was added to a $9 \mathrm{~mL}$ each sample for complete oxidation of iron(II) to iron(III) [22]. Then $20 \mu \mathrm{L}$ of each sample solution was used for the determination of iron(III), as in the procedure described above.

A sample of the standard metal alloy was prepared according to procedure previously reported [23]. The volume of $10 \mathrm{~mL}$ of this solution was treated with $\mathrm{H}_{2} \mathrm{O}_{2}$ (10 mass\%) for iron(II) oxidation. After the oxidation step, $20 \mu \mathrm{L}$ of this solution was used for the determination of total iron.

\section{RESULTS and DISCUSSION}

\section{Spectrophotometric Studies of the-Metal-NRS Complexes}

The reaction between iron and NRS using Job's method was investigated. The stoichiometry of the complex is Fe(III)-NRS=1:3 (Figure 3). The
$\mathrm{pH}$ factor is important for iron(III)-NRS complex formation. The absorbance (peak height) of iron(III)-NRS complex was studied by changing $\mathrm{pH}$ in the range of 2.0 to 7.0. The $\mathrm{pH}$ values were adjusted with the buffer solutions. As a consequence, the most suitable $\mathrm{pH}$ value of 4.0 was determined. Absorption spectra's those correspond to solutions of $5 \times 10^{-5} \mathrm{M}$ of iron(III)complex measured against all the other metalNRS complexes tested are shown in Figure 4 . The molar absorptivity at $\lambda_{\max }: 370 \mathrm{~nm}$ is $4.86 \times 10^{4}$ L. $\mathrm{mol}^{-1} . \mathrm{cm}^{-1}$.

Iron(III) subsequently reacted with $\mathrm{NRS}$ at $\mathrm{pH}$ 4.0 and formed iron(III)-NRS complex. Iron(III)NRS complex showed sharp absorption maximum at $\lambda_{\max }: 370 \mathrm{~nm}$. At this wavelength, 4, 1-nitroso2-naphthol-3,6 sulphonate has no absorption. The NRS complexes of all the metal ions with the anions tested show a negligible absorption. As can be seen, a large number of ions have no significant effect on the determination of iron(III). For tested metal ions whose tolerance limit has been studied, their tolerance ratios are given in Table 1.

\section{Optimization of the Method}

Various chemical variables of FIA system were optimized by use of the unvaried method at a fixed iron(III) concentration of $50 \mu \mathrm{g} . \mathrm{L}^{-1}$. The parameters of ionic strength and temperature was not taken into consideration in the study. Different molar excesses of NRS were added to a fixed metal ion concentration and absorbencies were measured according to the standard procedure. The NRS concentration was varied from $1 \times 10^{-6} \mathrm{M}$ to $1 \times 10^{-3}$

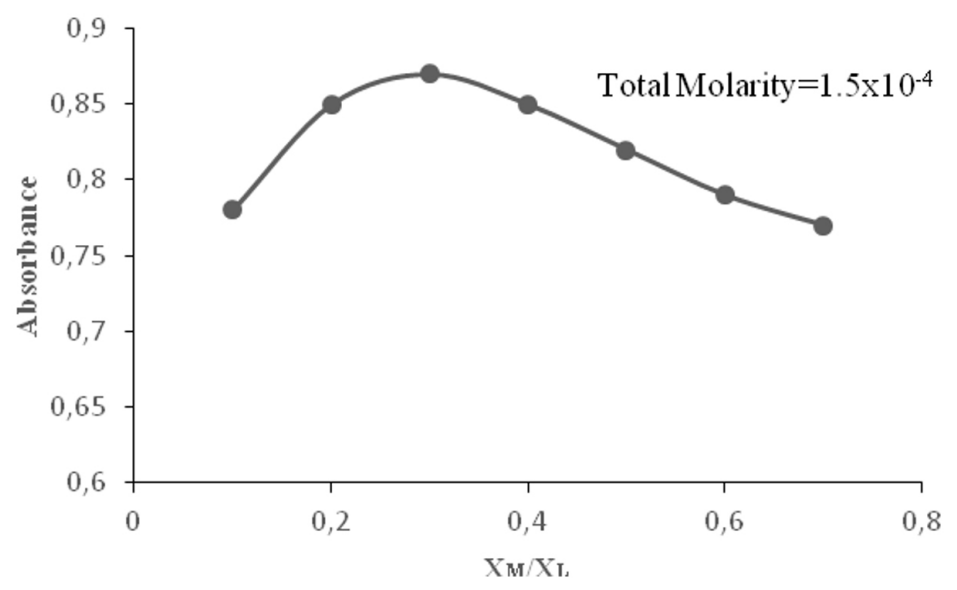

Figure 3. Composition of Fe(III)-NRS complex by Job's method. 


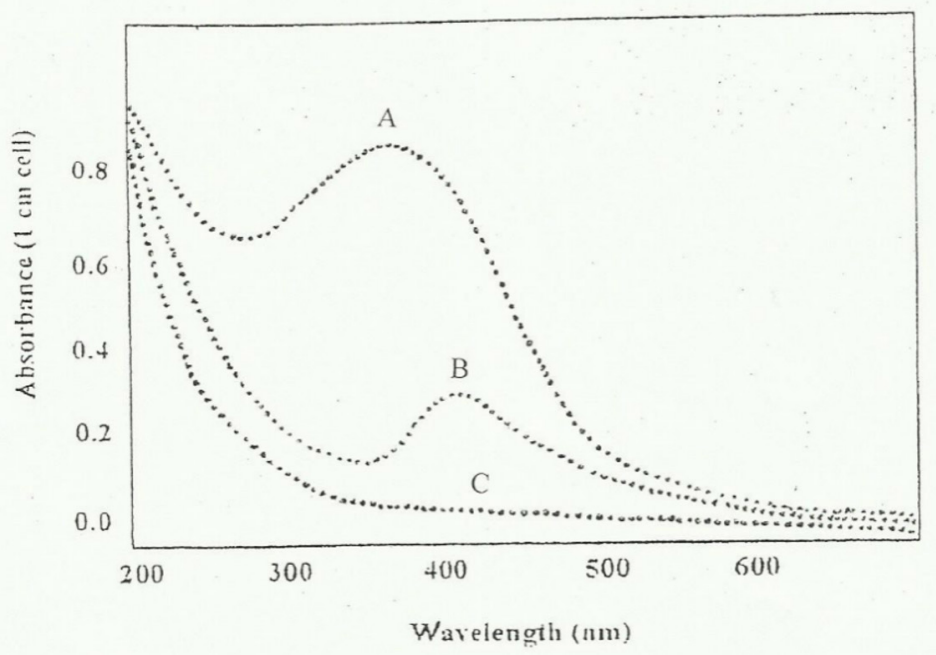

Figure 4. Absorption spectra of $5 \times 10^{-5} \mathrm{M}$ NRS and M-NRS complexes, A) Fe(III)-NRS, B) Fe(II)-NRS, C) NRS and M-NRS (M: $\mathrm{Cr}(\mathrm{III}), \mathrm{Al}(\mathrm{III}), \mathrm{Cu}(\mathrm{II}), \mathrm{Co}(\mathrm{II}), \mathrm{Cd}(\mathrm{II}), \mathrm{Mn}(\mathrm{II}), \mathrm{K}(\mathrm{I}), \mathrm{Na}(\mathrm{I}), \mathrm{Ag}(\mathrm{I}), \mathrm{Ca}(\mathrm{II}), \mathrm{Mg}(\mathrm{II}), \mathrm{Ba}(\mathrm{II}), \mathrm{Hg}(\mathrm{II})$.

M. The peak height was found to increase with increasing the NRS concentration up to $1 \times 10^{-5} \mathrm{M}$ and no noticeable increase was found at higher concentrations. Therefore, $5 \times 10^{-4} \mathrm{M}$ NRS reagent carrier solution was chosen as optimum because a wide linear range of the calibration curve, especially at low levels of iron(III) was obtained.

For all subsequent measurements, the concentration of the NRS fixed $5 \times 10^{-4} \mathrm{M}$, the $\mathrm{pH}$ of the carrier solution was varied from 3.0 to 5.0. The interference effect of the iron(II) were found to increase with increasing $\mathrm{pH}$ up to 4.0 and remain constant at higher $\mathrm{pH}$. Also, the peak heights were found to increase with increasing $\mathrm{pH}$ up to 4.0, remain constant to 4.0 and decreased slightly above that. The experiments showed that maximum complex formation was achieved at $\mathrm{pH}$ values between 3.0 and 5.0. The $\mathrm{pH}$ of the reagent carrier solution was adjusted to 4.0 to obtain maximum peak height and minimum iron(II) interference in the analysis.

The developed method, the effect of sample volume, mixing coil length and flow-rate was studied at the preferred concentration of the NRS and $\mathrm{pH}$, has been optimized. The sample volume was varied from 5-50 $\mu \mathrm{L}$. The peak height was decreased by decreasing sample size, and the peaks were broadened with increasing sample size due to sample zone dispersion. A sample injection volume of $20 \mu \mathrm{L}$ was selected as a compromise between sensitivity and sample throughput rate.
The reaction coil (RC) was examined to guarantee a sufficient mixing between the NRS and the sample or standard by using PTFE tubing's ( $0.5 \mathrm{~mm}$ i.d.) at different lengths ranging between 10 and $100 \mathrm{~cm}$. The peak height was increased with increasing mixing coil length from $10-50 \mathrm{~cm}$. The peak height was decreased for lower concentrations and broadened for higher concentrations at longer coil lengths. A mixing coil length $70 \mathrm{~cm}$ was decided convenient for better peak height and shape.

The flow-rate was varied from 0.5 to 1.5 $\mathrm{mL} . \mathrm{min}^{-1}$. The peak height decreased by increasing flow-rate. Taking into consideration of the stability of the pump, peak shape and sampling time, the flow-rate of the reagent carrier solution was adjusted $0.8 \mathrm{~mL} \cdot \mathrm{min}^{-1}$.

\section{Analytical Performance}

The developed analytical method was validated by evaluating the linear dynamic range, precision, accuracy, limit of detection (LOD) and limit of quantification (LOQ) by applying the calibration curve method. Under the preferred experimental conditions, a linear calibration graph was obtained for 0.1-100 $\mu \mathrm{g} . \mathrm{L}^{-1}$ iron(III) with a regression coefficient of 0.9992 . The limit of detection (blank signal plus three times the standard deviation of the blank) was $0.05 \mu \mathrm{g} . \mathrm{L}^{-1}$ and regression equation $Y=0.8821+75.5182 \mathrm{C}$, where $Y$ is the peak height $(\mathrm{cm})$ and $\mathrm{C}$ is concentration in $\mu \mathrm{g} \cdot \mathrm{L}^{-1}$. The precision of the method was investigated by five repetitive injections of 70 and $5 \mu \mathrm{g} \cdot \mathrm{L}^{-1}$ of iron(III) and the 
relative standard deviations were 1.46 and $3.12 \%$, respectively. The sample throughput of the proposed method was almost $40 \pm 5 h^{-1}$.

\section{Interference Studies}

The interference effects of many metal ions and anions by standard addition on the determination of $50 \mu \mathrm{g} . \mathrm{L}^{-1}$ iron(III) at fixed concentration were examined. The results summarized in Table 1. The tolerable concentration of each diverse ion was taken as a highest concentration causing an error of $\pm 3 \%$. Most of the ions examined did not interfere with the determination of $50 \mu \mathrm{g} . \mathrm{L}^{-1}$ iron(III). The major interference was found from iron(II) at the amounts of $10 \mathrm{mg}^{-1} \mathrm{~L}^{-1}$ (Table 1). The proposed method can be successful applied for the determination of iron(III) and total iron.

Table 1. Tolerance limits of foreign ions on the determination of iron(III) ion of $50 \mu \mathrm{g} . \mathrm{L}^{-1}$ iron(III) ion.

\begin{tabular}{ll}
\hline Tolerance limit $\left(\mu \mathrm{g} \cdot \mathrm{L}^{-1}\right)$ & \multicolumn{1}{c}{ Foreign ions } \\
\hline$\leq 50000$ & $\mathrm{Cr}(\mathrm{III}), \mathrm{Al}(\mathrm{III}), \mathrm{Cd}(\mathrm{II}), \mathrm{Mn}(\mathrm{II})$, \\
& $\mathrm{K}(\mathrm{I}), \mathrm{Na}(\mathrm{I}), \mathrm{Ag}(\mathrm{I}), \mathrm{Ca}(\mathrm{II}), \mathrm{Mg}(\mathrm{II})$, \\
& $\mathrm{Ba}(\mathrm{II}), \mathrm{Co}(\mathrm{II}), \mathrm{Cu}(\mathrm{II}), \mathrm{Hg}(\mathrm{II}), \mathrm{CN} ;$ \\
& $\mathrm{NO}_{3} ; \mathrm{NO}_{2} ; \mathrm{SO}_{4}^{2-}, \mathrm{CO}_{3}^{2-}, \mathrm{Cl}^{-}, \mathrm{Br}^{-}$, \\
& $\mathrm{PO}_{4}^{3-}, \mathrm{NH}_{4}^{+}, \mathrm{SCN}^{-}$ \\
& \\
$\leq 300$ & $\mathrm{Fe}(\mathrm{II})$ \\
\hline
\end{tabular}

\section{Applications}

To evaluate the applicability of the proposed flow-injwction method, it was applied to the determination of iron(III) in river and sea water samples, and iron processing solutions. The samples collected from different sources were filtered and directly injected into the flow line by using calibration curve method. The analytical results obtained by the proposed method are in good agreement with the certified values as is shown in Table 2 . The values obtained from the calibration curve as shown in Table 3. Atomic absorption measurements taken in water samples are also given for comparison (Table 3). Statistical analysis of the results by $F$ - and $t$ - tests showed no significant difference between the accuracy and precision of the proposed and reference method. The results for iron(III) in water samples were also in goog agreement with results obtained by the AAS. The results are given in Table 3. The accuracy of the method was confirmed by analysing $\mathrm{Zn} /$ $\mathrm{Al} / \mathrm{Cu} 43 \mathrm{XZ3} \mathrm{F}$ standard reference material. The results obtained were in good agreement with the certified iron concentration (Table 2). Some reported procedures for iron determination are presented in the Table 4.

\section{CONCLUSIONS}

A new, simple, ultra-sensitive, and inexpensive flow-injection spectrophotometric procedure based on the NRS has been developed for the determination of iron(III) and total iron in a wide concentration range without employing any further care. The proposed method allows to measure iron concentrations directly in the

Table 2. Determination of total iron in standard reference material (SRM).

\begin{tabular}{|c|c|c|c|c|}
\hline SRM & Certified $(\mu \mathrm{g})$ & ${ }^{a}$ Found $(\mu \mathrm{g})$ & ${ }^{a}$ Recovery (\%) & ${ }^{b} \mathrm{RSD} \%$ \\
\hline $\mathrm{Zn} / \mathrm{Al} / \mathrm{Cu} 43 \mathrm{XZ3} \mathrm{F}$ & 0.083 & $0.086(0.02)$ & $101.25 \pm 0.34$ & 3.61 \\
\hline
\end{tabular}

(a) Mean of three determinations with $95 \%$ confidence level $\left(\mathrm{X} \pm \mathrm{ts} /\left(\mathrm{n}^{1 / 2}\right)\right.$

${ }^{(b)}$ Relative standard deviation.

Table 3. Determination of iron(III) and total iron in river and sea water samples.

\begin{tabular}{|c|c|c|c|c|c|}
\hline \multirow[b]{2}{*}{ Samples ${ }^{(1)}$} & \multirow{2}{*}{$\begin{array}{l}\text { Iron }(\mathrm{III})^{(2)}\left(\mu \mathrm{g} \cdot \mathrm{L}^{-1}\right) \\
\text { Found }^{(3)}\end{array}$} & \multicolumn{4}{|c|}{ Total iron ${ }^{(2)}\left(\mu \mathrm{g} \cdot \mathrm{L}^{-1}\right)$} \\
\hline & & Found $^{(3)}$ & AAS & $\mathrm{F}$-test ${ }^{(4)}$ & t-test $^{(5)}$ \\
\hline Organized industry water & $74.34(0.18)$ & $81.17(0.14)$ & $83.11(0.15)$ & 1.6 & 2.1 \\
\hline Baruthane sea water & $47.51(0.18)$ & $54.26(0.04)$ & $55.97(0.20)$ & 1.8 & 1.9 \\
\hline Mert river water & $38.33(0.24)$ & $42.33(0.02)$ & $43.76(0.09)$ & 2.3 & 1.7 \\
\hline
\end{tabular}

(1)Samples were collected at Samsun, Turkey.

(2) Values in parenthesis are the relative standard deviations for $n=5$ with confidence level of $95 \%$.

(3)The results found using the calibration graph.

(4) Tabulated value $F$ for $(4,4)$ degrees of freedom at $P=0.95$ is 6.39 .

(5) Tabulated value $t$ for 4 degrees of freedom at $P=0.95$ is 2.78 . 
Table 4. Comparison of selected reagents for the proposed FIA method and some reported procedures for iron determination.

\begin{tabular}{|c|c|c|c|}
\hline Reagent & $\begin{array}{l}\text { Limit of detection } \\
\left(\mu \mathrm{g} \cdot \mathrm{L}^{-1}\right)\end{array}$ & $\begin{array}{l}\text { Linear range } \\
\left(\mu \mathrm{g} \cdot \mathrm{L}^{-1}\right)\end{array}$ & Reference \\
\hline Norfloxacin & 10 & $2-14$ & {$[17]$} \\
\hline 3-Aminophtalhydrazide & 1.2 & $7.2-18.2$ & {$[18]$} \\
\hline 8-Hydroxy-quinoline & 2.5 & $1-12$ & [19] \\
\hline $\mathrm{SCN}^{-}$ & 0.3 & $5.6-44.8$ & {$[20]$} \\
\hline 1-Nitroso-2-naphthol-3,6 sulphonate & 0.05 & $0.1-100$ & Present work \\
\hline
\end{tabular}

sample without a matrix separation step. The method could be useful for application to various matrix in process control and in environmental monitoring. The method was successfully applied to the determination of iron in different types of water samples including river, sea and industry waste water samples. In addition to the simplicity of the method, the reagent used is commercially available and does not have a risk of serious toxicity, thus enhancing the potential applicability of the method for iron analysis in real samples, having good recovery, sensitivity, selectivity and rapidity.

\section{References}

1. C. Xiong, Z. Jiang, B. Hu, Speciation of dissolved $\mathrm{Fe}(\mathrm{II})$ and $\mathrm{Fe}(\mathrm{III})$ in environmental water samples by micro-column packed with N-benzoyl-Nphenylhydroxylamine loaded on microcrystalline naphthalene and determination by electrothermal vaporization inductively coupled plasma-optical emission spectrometry, Anal. Chim. Acta, 559 (2006) 113-119.

2. T.M. Florence, Electrochemical approaches to traceelement speciation in waters - A review, Analyst, 111 (1986) 489-505.

3. J. Mortatti, F.J. Krug, L.C.R. Pessenda, E.A.G. Zagatto, S.S. Jorgensen, Determination of iron in naturalwaters and plant-material with 1,10-phenanthroline by flow-injection analysis, Analyst, 107 (1982) 659-663.

4. J.T.M. de Jong, J. Das den, U. Bathmann, M.H.C. Stoll, G. Kattner, R.F. Nolting, H.J.W. de Baar, Dissolved iron at subnanomolar levels in the Southern Ocean as determined by ship-board analysis, Anal. Chim. Acta, 377 (1998) 113-124.

5. S. Blain, P. Trégue, Iron(II) and iron(III) determination in sea water at the nanomolar level with selective on-line preconcentration and spectrophotometric determination, Anal. Chim. Acta, 308 (1995) 425-432.

6. Y. Sohrin, S.I. Iwamoto, S. Akiyama, T. Fujita, T. Kugii, H. Obata, E. Nakayama, S. Goda, Y. Fujishima, H. Hasegawa, K. Ueda, M. Matsui, Determination of trace elements in seawater by fluorinated metal alkoxide glass-immobilized 8-hydroxyquinoline concentration and high-resolution inductively coupled plasma mass spectrometry detection, Anal. Chim. Acta, 363 (1998)
11-19.

7. X.P.Yan, N.J. Hendry, R. Kerrich, Speciation of dissolved iron(III) and iron(II) in water by on-line coupling of flow injection separation and preconcentration with inductively coupled plasma mass spectrometry, Anal. Chem., 72 (2000) 1879-1884.

8. P. Pulido-Tofiño, J.M. Barrero-Moreno Moreno, M.C. Pérez-Conde, A flow-through fluorescent sensor to determine $\mathrm{Fe}(\mathrm{III})$ and total inorganic iron, Talanta, 51 (2000) 537-545.

9. S. Schnell, S. Ratering K.H. Jansen, Simultaneous determination of iron(III), iron(II), and manganese(II) in environmental samples by ion chromatography, Environ. Sci. Technol., 32 (1998) 1530-1537.

10. S. Hirata, H. Yoshihara, M. Aihara, Determination of iron(II) and total iron in environmental water samples by flow injection analysis with column preconcentration of chelating resin functionalized with $\mathrm{N}$-hydroxyethylethylenediamine ligands and chemiluminescence detection, Talanta, 49 (1999) 1059-1067.

11. H. Bagheri, A. Gholami, A. Najafi, Simultaneous preconcentration and speciation of iron(II) and iron(III) in water samples by 2-mercaptobenzimidazole-silica gel sorbent and flow injection analysis system, Anal. Chim. Acta, 424 (2000) 233-242.

12. D.G. Themelis, P.D. Tzanavaras, F.S. Kika, M.C. Sofoniou, Flow-injection manifold for the simultaneous spectrophotometric determination of $\mathrm{Fe}(\mathrm{III})$ and $\mathrm{Fe}(\mathrm{III})$ using 2,2'-dipyridyl-2-pyridylhydrazone and a singleline double injection approach, Fresenius J. Anal. Chem., 371 (2001) 364-368.

13. D.A. Weeks, K.W. Bruland, Improved method for shipboard determination of iron in seawater by flow injection analysis, Anal. Chim. Acta, 453 (2002) 21-32.

14. D.L.Giokas, E.K. Paleologos, M.I. Karayannis, Speciation of $\mathrm{Fe}(\mathrm{II})$ and $\mathrm{Fe}(\mathrm{III})$ by the modified ferrozine method, FIA-spectrophotometry, and flame AAS after cloudpoint extraction, Anal. Bioanal. Chem., 373 (2002) 237-243.

15. Z.O. Tesfaldet, J.F. van Staden, R.I. Stefan, Sequential injection spectrophotometric determination of iron as $\mathrm{Fe}(\mathrm{II})$ in multi-vitamin preparations using 1,10-phenanthroline as complexing agent, Talanta, 64 (2004) 1189-1195.

16. Y. Udnan, J, Jakmunee, S. Jayasavati, G.D. Christian, R.E. Synovec. K. Grudpan, Cost-effective flow injection spectrophotometric assay of iron content in pharmaceutical preparations using salicylate reagent, Talanta, 64 (2004) 1237-1240.

17. T. Pojanagaroon, S. Watanesk, V. Rattanaphani, S. Liawrungrath, Reverse flow injection spectrophotometric determination of iron(III) using 
norfloxacin, Talanta, 58 (2002) 1293-1300.

18. D. Lannuzel, J. de Jong, V. Schoemann, A. Trevena, J-L Tison, L. Chou, Development of a sampling and flow injection analysis technique for iron determination in the sea ice environment, Anal. Chim Acta, 556 (2006) 476-483.

19. D.A. Weeks, K.W. Bruland, Improved method for shipboard determination of iron in seawater by flow injection analysis, Anal. Chim Acta, 453 (2002) 21-32.

20. H. Hwang, J. Kim, Development of an analytical method for the spectrometric simultaneous determination of $\mathrm{fe}^{2+}$ and $\mathrm{Fe}^{3+}$ ions using a technique of flow injection analysis, J. Korean Chem. Society, 46 (2002) 419-426.

21. M. Andac, A. Asan, I. Isildak, A simple flow injection spectrophotometric determination method for iron(III) based on 0-acetylsalicylhydroxamic acid complexation, Chem. Pap., 63 (2009) 268-273.
22. A. Asan, M. Andac, I. Isildak, Flow-injection spectrophotometric determination of nanogram levels of iron(III) with N,N-dimethylformamide, Anal. Sci., 19 (2003) 1033-1036.

23. A. Asan, M. Andac, I. Isildak, N. Tinkilic, Flow injection spectrophotometric determination of iron(III) using diphenylamine-4-sulfonic acid sodium salt, Chem. Pap., 62 (2008) 345-349.

24. S. Kruanetr, W. Thanasarakhan, U. Tengjaroenkul, B. Liawruangrath, S. Liawruangrath, A simple flow Injection spectrophotometric determination of ıron using nitroso-r salt as comlexing agent, J. Flow Injection Anal., 24 (2007) 114-118.

25. S. Kruanetr, S. Liawruangrath, N. Youngvises, A simple and green analytical method for determination of iron based on micro flow analysis, Talanta, 73 (2007) 4653. 